\title{
Treatment of neuromyelitis optica: an evidence based review
}

\author{
Tratamento da neuromielite óptica: uma revisão baseada em evidências \\ Douglas Sato 1,2, Dagoberto Callegaro², Marco Aurélio Lana-Peixoto ${ }^{3}, K_{a z u o ~ F u j i h a r a}$, on behalf of Brazilian \\ Committee for Treatment and Research in Multiple Sclerosis (BCTRIMS)
}

\begin{abstract}
Neuromyelitis optica (NMO) is an inflammatory disease of the central nervous system characterized by severe optic neuritis and transverse myelitis, usually with a relapsing course. Aquaporin-4 antibody is positive in a high percentage of NMO patients and it is directed against this water channel richly expressed on foot processes of astrocytes. Due to the severity of NMO attacks and the high risk for disability, treatment should be instituted as soon as the diagnosis is confirmed. There is increasing evidence that NMO patients respond differently from patients with multiple sclerosis (MS), and, therefore, treatments for MS may not be suitable for NMO. Acute NMO attacks usually are treated with high dose intravenous corticosteroid pulse and plasmapheresis. Maintenance therapy is also required to avoid further attacks and it is based on low-dose oral corticosteroids and non-specific immunosuppressant drugs, like azathioprine and mycophenolate mofetil. New therapy strategies using monoclonal antibodies like rituximab have been tested in NMO, with positive results in open label studies. However, there is no controlled randomized trial to confirm the safety and efficacy for the drugs currently used in NMO.
\end{abstract}

Key words: neuromyelitis optica, therapy, aquaporin 4, plasmapheresis, steroids, azathioprine, mycophenolic acid, monoclonal antibodies, mitoxantrone, cyclophosphamide, interferon-beta.

\section{RESUMO}

Neuromielite óptica (NMO) é uma doença inflamatória do sistema nervoso central caracterizada por grave neurite óptica e mielite transversa, com um curso usualmente recorrente. $\mathrm{O}$ anticorpo contra aquaporina-4 é positivo em grande porcentagem dos pacientes com $\mathrm{NMO}$ e se liga a este canal de água altamente expresso nos processos pediosos dos astrócitos. Devido à gravidade dos ataques de NMO e ao elevado risco de incapacidade, o tratamento deve ser instituído tão logo o diagnostico seja confirmado. Existem evidências crescentes de que pacientes com NMO respondem de forma diferente dos pacientes com esclerose múltipla (EM) e, portanto, os tratamentos utilizados na EM podem não ser adequados para NMO. Os quadros agudos de NMO são tratados com pulsos de corticosteroides em altas doses e plasmaférese. 0 tratamento de manutenção também deve ser instituído para evitar ataques subsequentes e é baseado em corticosteroides orais em baixas doses ou imunossupressores, como a azatioprina e o micofenolato mofetil. Novas estratégias de tratamento utilizando anticorpos monoclonais como rituximab têm sido avaliadas para NMO, com resultados positivos em estudos abertos. Entretanto, não existem estudos clínicos controlados, randomizados, para confirmar a segurança e eficácia dos tratamentos atualmente utilizados na NMO.

Palavras-Chave: neuromielite óptica, terapia, aquaporina 4, plasmaferese, esteróides, azatioprina, ácido micofenólico, anticorpos monoclonais, mitoxantrona, ciclofosfamida, interferon-beta.

Neuromyelitis optica (NMO) is an inflammatory disease of the central nervous system (CNS) characterized by severe optic neuritis (ON) and transverse myelitis (TM)1. Aquaporin-4 (AQP-4) antibody, also known as NMO-IgG, an autoantibody exclusively detected in the sera of NMO, is directed against AQP-4, a water channel richly expressed on foot processes of astrocytes in the $\mathrm{CNS}^{2,3}$. In most series of
NMO, more than half of cases are positive for AQP-4 antibody. In 2006, Wingerchuk et al. ${ }^{4}$ proposed the revised diagnostic criteria of NMO that incorporated AQP-4 antibody status. For definite NMO, the criteria require (A) ON, (B) TM and (C) at least two of three supportive criteria: (1) contiguous spinal cord lesion in the magnetic resonance imaging (MRI) extending over three vertebral segments; (2) brain MRI not meeting

${ }^{1}$ Department of Neurology, Tohoku University Graduate School of Medicine, Sendai, Japan;

${ }^{2}$ Department of Neurology, Faculty of Medicine, University of São Paulo (USP), São Paulo SP, Brazil;

${ }^{3}$ CIEM Multiple Sclerosis Research Center, Federal University of Minas Gerais Medical School, Belo Horizonte MG, Brazil;

${ }^{4}$ Department of Multiple Sclerosis Therapeutics, Tohoku University Graduate School of Medicine, Sendai, Japan.

Correspondence: Douglas Sato; Department of Neurology; Tohoku University Graduate School of Medicine; 1-1, Seiryomachi, Aobaku; 980-8574 Sendai Miyagi - Japan; E-mail: douglas.sato@med.tohoku.ac.jp

Conflict of interest: There is no conflict of interest to declare.

Received 29 August 2011; Accepted 05 September 2011 
diagnostic criteria for multiple sclerosis (MS); (3) serum positivity for AQP-4 antibody.

NMO treatment has two main objectives: one is to control the inflammatory damage in acute attacks and the other one is a maintenance treatment to avoid relapses. The former is based on high dose intravenous corticosteroids and plasmapheresis ${ }^{5}$; the latter is based on low-dose corticosteroids and immunossupressants ${ }^{6,7}$. Additionally, there is evidence that AQP-4 antibody titers are reduced in patients without relapses under immunosuppressant treatment ${ }^{8,9}$. Although NMO attacks are related to severe disability, there are some evidences that NMO patients remain neurologically stable between them, without evidence of progressive deterioration like in $\mathrm{MS}^{1}$. Therefore, it is crucial that treatment is started as early as possible to avoid new relapses and further disability.

For this review, the English-language literature was systematically searched using Pubmed (National Library of Medicine) with the keywords neuromyelitis optica, and treatment was accessed on $20^{\text {th }}$ July 2011, resulting in 394 articles. All articles available had the abstract analyzed and full article review was performed once considered relevant. Additional articles referenced in bibliographies from these articles were also reviewed. Case reports that revealed further insights into NMO, not identified in case series analyzed, were included in this review.

\section{LEVELS OF EVIDENCE}

In this review, we used levels of evidence from the Agency for Health Care Policy and Research (also known as Agency for Healthcare Research and Policy) ${ }^{10}$ (Table 1) and the recommendation grades published for use in clinical guidelines from the American College of Chest Physicians Task Force (Table 2) ${ }^{11}$. We have classified the available studies in NMO accordingly and provided the recommendations for each treatment (Table 3).

\section{CORTICOSTEROIDS}

Corticosteroids have been the mainstay treatment for NMO in both acute and maintenance phase. Methylprednisolone has been used since 1970 as a potent anti-inflammatory or immunosuppressant agent in the treatment of a variety of diseases including those of hematologic, allergic, inflammatory, neoplastic and autoimmune origin. In addition, it is also widely used in prevention and treatment of graft-versus-host disease following allogeneic bone marrow transplantation and acute spinal cord injury. Corticosteroids exert a wide array of physiologic effects including modulation of carbohydrate, protein and lipid metabolism, and maintenance of fluid and electrolyte homeostasis. Moreover, cardiovascular, immunologic, musculoskeletal, endocrine and neurologic physiologic functions are influenced by corticosteroids. Therefore, not only the positive effects can be observed, but also many adverse events can be originated from corticosteroids use. These adverse events can be seen acutely like mood/psychic changes, fluid retention with circulatory overload, hyperglycemia, hypokalemia and increased ocular pressure. Chronic corticosteroid use may promote other side effects like hypertension, hirsutism, Cushing's syndrome, hyperlipidemia, diabetes mellitus, gastrointestinal hemorrhage, aseptic necrosis and bone fractures.

The mechanism of action of corticosteroids is not completely understood, but many of their genomic functions originate from regulation of gene expression subsequent to binding specific intracellular receptors and translocation into the nucleus ${ }^{12}$. More recently, there have been observed evidences that corticosteroids in high doses, as used in high dose intravenous methylprednisolone (HIMP), have significant non-genomic effects, which may explain the rapid clinical response after infusion. These effects are probably mediated by a direct effect on cellular membranes and mitochondrial function, inducing a reduction of adenosine-5'-triphosphate production and promoting cellular apoptosis. Furthermore, HIMP also reduces the mitogen-induced increase of cytoplasmic calcium concentration and inhibits cation cycling across the plasma membrane with only a minimal effect on intracellular protein synthesis. The genomic and non-genomic effects may explain the positive effects of corticosteroids in NMO, inducing a reduction of inflammation, apoptosis of leukocytes, suppression of migration of polymorphonuclear leukocytes and reversal of increased capillary permeability.

Although the clinical efficacy of corticosteroids have been established in meta-analysis evaluating the treatment of neuroimmunological diseases ${ }^{13}$, only few clinical studies have rigorously investigated the efficacy and safety of corticosteroids in NMO. Consequently, the current practice of corticosteroids use in NMO is mainly based on few open-label studies and personal experience on treating other CNS autoimmune diseases.

The first open-label study in NMO evaluated the treatment of seven newly diagnosed NMO patients with long-term prednisone and azathioprine, with a follow-up every two months for at least 18 months $^{6}$. Patients had no relapses during the observation period, and Expanded Disability Status Scale (EDSS) reduced from a mean of 8.2 at baseline to 4 at 18 months. A subsequent study reviewed related 25 patients with NMO who met the 1999 Wingerchuk's criteria and identified nine patients with long-term use of corticosteroid monotherapy ${ }^{7}$. The annual relapse rate was significantly lower under use of corticosteroids than the period without the drug (median 0.49 vs. 1.48). Still more interesting, the authors also observed that the odds ratio for the period with $10 \mathrm{mg} /$ day or less was 8.71 if compared with $10 \mathrm{mg} /$ day or over, suggesting that dose tapering below $10 \mathrm{mg} /$ day for relapse prevention should be prescribed carefully, as it may be less than the required for the majority of patients for relapse prevention. 
Another evidence that corticosteroids are useful to preserve normal nerve function in NMO is a retrospective study on NMO patients with optic neuritis relapse, which correlated the number of relapses, early corticosteroids intervention and a loss in retinal nerve fiber layer thickness (RNFLT) ${ }^{14}$. The overall RNFL was thinner in patients in the NMO group than in the MS (63.84 vs. $84.28 \mu \mathrm{m})$. The frequency of the ON relapses and the time for beginning the treatment with HIMP significantly affected the preservation of the RNFLT.

\section{PLASMAPHERESIS}

Plasmapheresis (PE) has been used as an alternative therapy for autoimmune diseases when HIMP is not effective. PE
Table 1. Classification of evidence levels ${ }^{10}$.
la Evidence obtained from meta-analysis of randomized controlled trials

Ib Evidence obtained from at least one randomized controlled trial

Ila Evidence obtained from at least one well-controlled study without randomization

Ilb Evidence obtained from at least one other type of welldesigned quasi-experimental study

III Evidence obtained from well-designed, non-experimental descriptive studies; such as comparative studies, correlation studies and case control studies

IV Evidence obtained from expert committee reports or opinions and/or clinical experience of respected authorities

Table 2. Grading recommendations ${ }^{11}$.

\begin{tabular}{|c|c|c|c|}
\hline Recommendation & Description & Methodological quality of supporting evidence & Implications \\
\hline Grade 1A & $\begin{array}{l}\text { Strong recommendation, } \\
\text { high-quality evidence }\end{array}$ & $\begin{array}{l}\text { RCTs without important limitations or } \\
\text { overwhelming evidence from observational studies }\end{array}$ & $\begin{array}{l}\text { Strong recommendation, can } \\
\text { apply to most patients in most } \\
\text { circumstances without reservation }\end{array}$ \\
\hline Grade 1B & $\begin{array}{l}\text { Strong recommendation, } \\
\text { moderate-quality } \\
\text { evidence }\end{array}$ & $\begin{array}{l}\text { RCTs with important limitations (inconsistent } \\
\text { results, methodological flaws, indirect or } \\
\text { imprecise) or exceptionally strong evidence from } \\
\text { observational studies }\end{array}$ & $\begin{array}{l}\text { Strong recommendation, can } \\
\text { apply to most patients in most } \\
\text { circumstances without reservation }\end{array}$ \\
\hline Grade 1C & $\begin{array}{l}\text { Strong recommendation, } \\
\text { low-quality or very low- } \\
\text { quality evidence }\end{array}$ & Observational studies or case series & $\begin{array}{l}\text { Strong recommendation, but } \\
\text { may change when higher quality } \\
\text { evidence becomes available }\end{array}$ \\
\hline Grade 2A & $\begin{array}{l}\text { Weak recommendation, } \\
\text { high-quality evidence }\end{array}$ & $\begin{array}{l}\text { RCTs without important limitations or } \\
\text { overwhelming evidence from observational studies }\end{array}$ & $\begin{array}{l}\text { Weak recommendation, best } \\
\text { action may differ depending on } \\
\text { circumstances or patients or } \\
\text { societal values }\end{array}$ \\
\hline Grade 2B & $\begin{array}{l}\text { Weak recommendation, } \\
\text { moderate-quality } \\
\text { evidence }\end{array}$ & $\begin{array}{l}\text { RCTs with important limitations (inconsistent } \\
\text { results, methodological flaws, indirect or } \\
\text { imprecise) or exceptionally strong evidence from } \\
\text { observational studies }\end{array}$ & $\begin{array}{l}\text { Weak recommendation, best } \\
\text { action may differ depending on } \\
\text { circumstances or patients or } \\
\text { societal values }\end{array}$ \\
\hline Grade 2C & $\begin{array}{l}\text { Weak recommendation, } \\
\text { low-quality or very low- } \\
\text { quality evidence }\end{array}$ & Observational studies or case series & $\begin{array}{l}\text { Weak recommendation, other } \\
\text { alternatives may be equally } \\
\text { reasonable }\end{array}$ \\
\hline
\end{tabular}

RCT: Randomized controlled trial.

Table 3. Summary of treatments and recommendation levels used for neuromyelitis optica.

\begin{tabular}{|c|c|c|c|}
\hline Treatment & Dose/Regimen & Recommendation & Evidence level \\
\hline \multicolumn{4}{|l|}{ Acute attacks } \\
\hline Corticosteroid pulse (HIMP) & Methylprednisolone $1 \mathrm{~g} /$ day for 3 to 5 days & Grade 1C & III \\
\hline Plasmapheresis (PE) & $2 \sim 4$ liters per session, 2 to 3 sessions per week, up to 7 sessions & Grade 1C & Ilb \\
\hline \multicolumn{4}{|l|}{ Relapse prevention } \\
\hline Oral prednisone & $5 \sim 20 \mathrm{mg} / \mathrm{day}$ & Grade 1C & III \\
\hline Azathioprine & $2 \mathrm{mg} / \mathrm{kg} / \mathrm{day}$ & Grade $1 \mathrm{C}$ & III \\
\hline Mycophenolate mofetil & 2 g/day & Grade $1 \mathrm{C}$ & III \\
\hline Rituximab & $\begin{array}{l}375 \mathrm{mg} / \mathrm{m}^{2} / \text { week for } 4 \text { weeks or } 1 \mathrm{~g} \text { repeated in } 2 \text { weeks; } \\
\text { monitoring of CD } 19+\text { or CD } 27+\text { B cells to indicate retreatment }\end{array}$ & Grade 1C & III \\
\hline Immunoglobulin (IVIG) & $400 \mathrm{mg} / \mathrm{kg}$ for 5 days monthly & Grade 2C & IV \\
\hline Mitoxantrone & $12 \mathrm{mg} / \mathrm{m}^{2} / \mathrm{month}$, maximum cumulative dose $140 \mathrm{mg} / \mathrm{m}^{2}$ & Grade 2C & III \\
\hline Cyclophosphamide & $1 \mathrm{~g} /$ day monthly or immunoablation with $2 \mathrm{~g} /$ day for 4 days & Grade 2C & IV \\
\hline
\end{tabular}

HIMP: High-dose intravenous methylprednisolone; PE: plasmapheresis; IVIG: intravenous immunoglobulin. 
is an extracorporeal blood purification technique designed to remove antibodies, complement, cytokines and chemokines from the plasma. The quick removal of these substances may reduce further damage and interrupt the advancement of lesions faster than immunosuppressive agents, as autoantibodies can persist for several weeks in the circulation. It has been largely used for the treatment of thrombotic thrombocytopenic purpura, myasthenia gravis, chronic inflammatory demyelinating polyneuropathy, Waldenstrom macroglobulinemia and Guillain-Barré syndrome ${ }^{15}$. MS, NMO, acute disseminated encephalomyelitis, Lambert-Eaton myasthenic syndrome, paraproteinemic polyneuropathy and cryoglobulinemic polyneuropathy are some other neurological conditions sometimes treated with apheresis ${ }^{16}$. Due to the success in other immune mediate diseases, PE is used in NMO taking into consideration that there is evidence that NMO is an autoantibody-mediated disease with complement activation and PE has the potential to remove humoral immune products from systemic circulation ${ }^{17}$.

$\mathrm{PE}$ is often prescribed using at least five plasma exchange sessions to achieve a sufficient antibody removal. The rate of extravascular to intravascular equilibration is approximately one to two percent per hour, then five separate exchanges over seven to ten days are required to remove $90 \%$ of the total initial body immunoglobulin levels ${ }^{18}$. In order to be most effective, PE has to be associated with appropriate immunosuppressant therapy, avoiding new immunoglobulin production. If antibody production is not properly blocked, additional PE sessions may be required.

$\mathrm{PE}$ is an invasive therapeutic procedure and carries some complications. In NMO, it is usually performed using 5\% albumin replacement, so complications from fresh frozen plasma infusion are avoided. Reported adverse effects have been hypotension, dyspnea/pulmonary edema due to fluid overload, citrate induced hypocalcaemia, coagulation abnormalities, infection and catheter related issues. As PE can also promote removal from serum of drugs such as azathioprine and cyclophosphamide; it is advisable that these drugs are administered following apheresis sessions ${ }^{19}$.

There is some evidence from some case series that PE is effective for acute relapse treatment in NMO patients who did not respond satisfactorily to HIMP ${ }^{5,17,20,21}$. Moreover, clinical response seems to be related to the early initiation of treatment ${ }^{20}$ and it may be observed quickly once PE sessions are started $^{5}$. A review from the American Academy of Neurology about PE in neurological diseases indicates that there is Class II evidence that PE is probably effective to treat fulminant CNS diseases, including $\mathrm{NMO}^{22}$. However, the randomized study which provided such evidence included 22 patients with various CNS demyelinating diseases, like MS, ADEM, Marburg's disease, but only four patients with acute myelitis and two patients with $\mathrm{NMO}^{23}$. Other small case series have reported positive results with double membrane filtration plasmapheresis (instead of centrifugation technique $)^{24}$ and PE used as rescue therapy ${ }^{25}$.

The Guidelines on the use of therapeutic apheresis in clinical practice from the American Society for Apheresis published in $2010^{26}$ considered that PE for NMO is accepted as second line therapy, as it may be helpful in recovery from acute attacks, although it does not prevent further relapses.

For long-term treatment, there is only a small case-series study $(n=4)$ indicating that PE is effective not only for acute management, but also intermittent PE may be worthwhile for selected cases where long-term immunosuppressant treatment have failed ${ }^{21}$.

\section{AZATHIOPRINE}

Azathioprine is a DNA synthesis inhibitor, as it is converted to a purine analogue, with interference in the purines synthesis (adenine and guanine). It inhibits the proliferation of cells, especially lymphocytes. The clinical effects are usually not seen before three to six months after initiation of therapy. It is a reasonably well-tolerated drug used for autoimmune diseases and organ transplantation either alone or in combination. It has been approved as adjunctive therapy in prevention of rejection of kidney transplants and for the management of active rheumatoid arthritis ${ }^{27}$. Additionally, many off-label uses have been reported, such as adjunct in prevention of solid organ transplants rejection, steroid-sparing agent for corticosteroiddependent Crohn's disease and ulcerative colitis, dermatomyositis/polymyositis, MS and other autoimmune diseases.

Common adverse events reported with azathioprine include: fever, malaise, nausea, vomiting, leukopenia, thrombocytopenia, hepatoxicity, myalgia, and infections. It is reported a slight higher risk of developing cancer ${ }^{27}$. Therefore, periodic monitoring of patients with hematological (complete blood count with differential and platelets), liver function tests, bilirubin and continuous surveillance for clinical signs of cancer are required.

More recently, there is increasing evidence to evaluate thiopurine methyltransferase enzyme activity before initiating azathioprine therapy ${ }^{28}$. Thiopurine methyltransferase enzyme is involved in the metabolism of azathioprine and may determine the clinical response to thiopurines. Patients with intermediate or low thiopurine methyltransferase activity may be at risk for increased myelosuppression, sometimes life-threatening. Therefore, careful monitoring and dose adjustments may be required for these patients.

As previously described, the first study included seven newly diagnosed NMO patients with long-term combination of corticosteroids and azathioprine with positive results ${ }^{6}$. HIMP was given first for five days, followed by oral prednisone ( $1 \mathrm{mg} / \mathrm{kg} /$ day) for two months daily. At week three, patients started azathioprine ( $2 \mathrm{mg} / \mathrm{kg} /$ day). Two months later, 
patients began prednisone tapering very slowly until they have achieved a dose of $10 \mathrm{mg} /$ day and azathioprine doses of 75 to $100 \mathrm{mg} /$ day. Another study observed that suspension of azathioprine was followed by increase in AQP-4 antibody levels and clinical attacks in some patients, together with the interruption of corticosteroid in two patients or the maintenance of low-dose corticosteroid treatment ( $5 \mathrm{mg} /$ day $)^{9}$. A retrospective study with 36 Brazilian NMO patients analyzed those who used azathioprine alone or in combination with corticosteroids and provided similar findings of reduction in disability and relapse rates ${ }^{29}$. These results may indicate that combination therapy may be required in some patients. However, there are no multicenter controlled studies to provide class I efficacy evidence of this therapeutic regimen, and side effects may limit the use in some patients.

\section{RITUXIMAB}

Rituximab is a chimeric monoclonal antibody against the protein CD20, which is primarily found on the surface of B cells and it has the property to eliminate B cells selectively. Rituximab binds to the antigen on the cell surface, activating complement-dependent B cell cytotoxicity. It also binds to human Fc receptors, mediating cell killing through an antibody-dependent cellular toxicity. Rituximab is used in the treatment of many lymphomas, leukemias, transplant rejection and some autoimmune disorders. Besides the clinical studies with rituximab, another evidence that $B$ cells and AQP-4 antibody are closely related to NMO pathogenesis is a case report of a Japanese NMO patient with hypogammaglobulinemia secondary to carbamazepine who reported no relapses during the lowered IgG levels, but who had no attacks relapsed later when the hypogammaglobulinemia resolved in association with the normalization of CD19+ cells ${ }^{30}$.

The first published open label study included eight patients in the USA, where rituximab was well tolerated, and positive response was observed in all patients with significant relapse reduction (2.6 relapse/patient/year to 0 ) and recovery of neurologic function measured by EDSS from 7.5 to $5.5^{31}$. Rituximab was administered in four infusions of $375 \mathrm{mg} / \mathrm{m}^{2}$, administered once per week, and B cells were monitored with CD19 marker by flow cytometry. In the retreatment, the regimen used was 1,000 mg administered two weeks apart. However, one patient who did not receive the repeated course of rituximab when planned had an attack, indicating that treatment requires repeated infusions in order to CD19+ cells remain undetectable. A report of three Japanese NMO cases who received rituximab also observed positive results, with a remarkable reduction in the annualized relapse rate (from 5.0 in the pre-treatment to 0.6 in the post-treatment), but the decrease in EDSS was not so significant (from 8.7 in the pre-treatment to 8.0 post-treatment), maybe indicating that, although the drug was effective to control the inflammatory response, the irreversible damage had already been established ${ }^{32}$. Another study described two NMO cases treated with rituximab ${ }^{33}$. It was observed a good clinical response in one patient, but the other one have experienced relapses after the treatment, indicating that not all patients respond so well. A possible explanation for the occurrence of relapses following initiation of rituximab in some NMO patients is the transient increase in AQP-4 antibody titers and of B cell activating factor levels, which is observed for two weeks following the initial infusion ${ }^{34}$. Posterior reversible encephalopathy syndrome after rituximab infusion in NMO have been reported ${ }^{35}$, but this syndrome has been reported in NMO patients independent of rituximab ${ }^{36}$, so this may be a relapse related to rituximab initiation rather than a new treatment complication.

Another study retrospectively analyzed $25 \mathrm{NMO}$ patients identified in seven centers from USA and Europe ${ }^{35}$. It was observed a marked reduction in the attacks and improvement in disability. The study had the two regimen of rituximab used in previous studies analyzed together ( four infusions of $375 \mathrm{mg} / \mathrm{m}^{2}$, administered once per week, and 1,000 mg administered two weeks apart). The median follow-up was 19 months, and the mean post-treatment relapse rate dropped from 1.7 to 0 . Disability has improved in $80 \%$ of patients, but two patients died during the study period, one due to a brainstem relapse and the other due to suspected septicemia. The study indicated a promising treatment option, but, like the traditional chemotherapies, it may expose patients to severe infections. Another retrospective study in the USA has also revealed that rituximab treatment was associated with reduction of relapses and stabilization or improvement of disability ${ }^{36}$.

A study with eight European patients evaluated the clinical response and AQP-4 antibody titers with different treatments, measured by a fluorescence immunoprecipitation assay using an extract from cells transfected with EGFP-tagged human AQP-4 M1 and M23 isoforms ${ }^{9}$. Four patients received rituximab and the reduction of $\mathrm{CD} 19+$ cells was correlated with a reduction of AQP-4 antibody titers and positive clinical response. The study also identified that relapses were preceded or paralleled by reoccurrence of CD19+ cells and an increase up to three-fold in the AQP-4 antibody. Another group has also confirmed clinical efficacy of rituximab in $10 \mathrm{NMO}$ patients in Europe, but there was no correlation with AQP-4 antibody levels ${ }^{37}$.

Recently, the results of an open-label study with Korean $\mathrm{NMO}$ patients were reported with positive results ${ }^{38}$. Induction therapy was basically the same of previous studies, followed by maintenance therapy with repeated rituximab infusions (375 mg/m², once) when the frequency of CD27+ memory B cells was more than $0.05 \%$ in peripheral blood. Interestingly, this approach reduced the number of infusions in the maintenance therapy, with a direct impact on treatment costs. Twenty-eight of 30 patients (93\%) showed a marked reduction 
in the mean relapse rate from 2.4 to 0.3 while receiving rituximab over 24 months. Seventy percent of patients became relapse-free over 24 months, and disability either improved or stabilized in great majority of patients. One patient continued to have relapses despite rituximab treatment and was switched to mitoxantrone hydrochloride, and another patient had three relapses during treatment, but two relapses were associated with delayed retreatment. AQP-4 antibody levels declined significantly following treatment with rituximab, consistent with the clinical response and the effect on memory B cells. The most common infusion-related reactions, noted in $40 \%$ of patients during the first infusion, were transient hypotension and mild to moderate flu-like symptoms, such as a febrile sense, headache and skin rash. Less than half of patients experienced at least one infection episode during the study period, but there were no serious infection. There was no decline in serum total IgG titers, and no patient became seropositive for the JC virus over the 24 months.

\section{MITOXANTRONE}

Mitoxantrone hydrochloride is an anthracenedione used as an antineoplastic agent for prostate cancer and acute nonlymphocytic leukemia in adults. It has been approved for MS treatment, including secondary progressive MS, based on the evidence that it has reduced progression in MS patients with failure in other treatment regimens. It also reduces the clinical relapse rate and MRI outcomes in relapsing-remitting MS patients, and it is helpful on patients with clinical worsening conditions. However, the potential toxicity of this drug limits its use, and patients should be monitored periodically for cardiac, liver and kidney function ${ }^{39}$.

Considering the successful use in MS, mitoxantrone has been evaluated in NMO patients, but the case series have been very limited. In a study, five NMO patients received monthly intravenous infusions of mitoxantrone hydrochloride, $12 \mathrm{mg} / \mathrm{m}^{2}$, for six months, followed by three additional treatments every three months ${ }^{40}$. During the two years period of treatment, two patients had a relapse within the initial five months of treatment (one severe and one moderate), and improvement was seen clinically and on magnetic resonance images in four patients. One patient had a reversible decrease in cardiac ejection fraction. In another study, there were three patients who received mitoxantrone ${ }^{9}$. Unfortunately, the response was variable, from reduction of relapse rate in one patient to increased relapse rate in two patients.

\section{MYCOPHENOLATE MOFETIL}

Mycophenolate mofetil has been largely used for the treatment of several autoimmune diseases. It has a selective cytostatic effect on $\mathrm{T}$ and B lymphocytes. It is an inhibitor of inosine monophosphate dehydrogenase, which inhibits de novo guanosine nucleotide synthesis, required for proliferation of $\mathrm{T}$ and $\mathrm{B}$ lymphocytes. It has been used for prevention of organ transplants rejection and autoimmune diseases, like myasthenia gravis and systemic lupus erythematosus.

In 2006, a case report described a NMO patient successfully treated with mycophenolate mofetil $2 \mathrm{~g} /$ day who had no relapses over the following two years associated with clinical improvement ${ }^{41}$. Another study analyzed retrospectively 24 patients treated with mycophenolate mofetil (median dose of $2 \mathrm{~g}$ /day) with median treatment duration of 27 months. Patients had reduction in relapse rates (median annualized rate dropped from 1.28 to 0.09 ) and $91 \%$ of patients had stabilization or improvement of disability. In this study, six patients $(25 \%)$ reported adverse events, which included headache, constipation, easy bruising, anxiety, hair loss, diarrhea and abdominal pain, and low white blood cell counts that required discontinuation ${ }^{42}$.

\section{CYCLOPHOSPHAMIDE}

Cyclophosphamide is an alkylating agent that prevents cell division by cross-linking DNA strands and decreasing DNA synthesis. It is a cell cycle phase nonspecific agent and has immunosuppressant activity. Cyclophosphamide is a prodrug that must be metabolized to active metabolites in the liver. It has been used in the treatment of many neoplasias and some autoimmune diseases, like severe rheumatoid disorders, Wegener's granulomatosis, myasthenia gravis, MS, systemic lupus erythematosus, autoimmune hemolytic anemia and idiopathic thrombocytopenic purpura.

However, most studies are based on open-label studies or case series. In MS, the largest study from the Canadian Co-operative Multiple Sclerosis Study Group with 168 patients failed to demonstrate clinical efficacy of cyclophosphamide ${ }^{43}$. Another study has indicated some beneficial effects of cyclophosphamide in young MS patients, excluding those with primary progressive MS. In this study, the responsive patients received repeated cyclophosphamide infusions in a bimonthly basis after the induction phase ${ }^{44}$. Common adverse events of cyclophosphamide include: alopecia, fertility issues, nausea and vomiting, anorexia, diarrhea, mucositis, acute hemorrhagic cystitis or urinary fibrosis, anemia, leukopenia (dose-related with recovery from seven to ten days after cessation) and thrombocytopenia.

In NMO, there is scarce data, based mainly in case reports. The use of cyclophosphamide has been reported as effective in immunoablative doses (2,000 mg/day for 4 days) in a patient with $\mathrm{NMO}$ associated with refractory systemic lupus erythematosus after response failure with other treatments, like HIMP, intravenous immunoglobulin (IVIG) and 
rituximab ${ }^{45}$. However, another case report indicated a failure of monthly cyclophosphamide pulse $\left(1,000 \mathrm{mg} / \mathrm{m}^{2}\right)$ for six months, although NMO relapses were controlled with rituximab ${ }^{46}$.

\section{INTERFERON BETA}

The therapy using interferon beta has been used in MS treatment in routine practice for over 15 years. However, interferon beta is not currently recommended for NMO patients and there are some evidences that it also may be even harmful, increasing the relapse rates ${ }^{47}$. Other Japanese studies reported MS patients with good response to interferon beta therapy, compared with NMO patients who experienced increased relapse rate after interferon beta treatment ${ }^{48,49}$. Similarly, a series of 25 NMO patients from France were reported to experience relapses following treatment with interferon beta ${ }^{50}$. Additionally, there is a case report of a Caucasian NMO patient from United Kingdom ${ }^{51}$, suggesting that this deleterious response to interferon beta is probably not influenced by racial differences.

\section{OTHER THERAPIES AND FUTURE PERSPECTIVES}

Eculizumab is a humanized monoclonal $\operatorname{IgG}$ antibody that binds to complement protein $\mathrm{C} 5$, preventing cleavage into $\mathrm{C} 5 \mathrm{a}$ and $\mathrm{C} 5 \mathrm{~b}$. Eculizumab inhibits the subsequent formation of terminal complex C5b-9 or membrane attack complex. It is currently under investigation for NMO in an open- label phase I clinical trial at a single center with 14 patients ${ }^{52}$. Eculizumab has already been shown to be effective in paroxysmal nocturnal hemoglobinuria ${ }^{53}$. Each patient will receive eculizumab at a dose of $600 \mathrm{mg}$ each week for four weeks, then $900 \mathrm{mg}$ at the fifth week, and $900 \mathrm{mg}$ every two weeks for 48 weeks.

Anecdotal reports have been published using intravenous immunoglobulin ${ }^{54}$, glatiramer acetate ${ }^{55}$, but replication of these findings needs to be validated by other studies in a larger number of patients.

Other monoclonal antibodies used in MS treatment have been tried in NMO patients refractory to established treatments, like natalizumab, but NMO patients seem to not respond to these therapies (personal communication with Dr Anu Jacob, The Walton Centre, Liverpool UK, unpublished).

\section{FINAL REMARKS}

The use of corticosteroids and other immunosuppressant drugs for NMO treatment has been based on case reports or small series of cases rather than in double-blinded randomized studies. This does not mean that these drugs are not effective, but that higher levels of evidence of their effectiveness are still lacking. As NMO is a very severe and incapacitating CNS disorder, its treatment has to be decided on the basis of clinical judgment, physicians' experience, case series and extrapolation from management of other autoimmune conditions while clinical trials are not yet available to provide physicians with options grounded on stronger scientific support.

\section{References}

1. Wingerchuk DM, Hogancamp WF, O'Brien PC, Weinshenker BG. The clinical course of neuromyelitis optica (Devic's syndrome). Neurology 1999;53:1107-1114.

2. Lennon VA, Wingerchuk DM, Kryzer TJ, et al. A serum autoantibody marker of neuromyelitis optica: distinction from multiple sclerosis. Lancet 2004;364:2106-2112.

3. Pittock SJ, Weinshenker BG, Lucchinetti CF, Wingerchuk DM, Corboy JR, Lennon VA. Neuromyelitis optica brain lesions localized at sites of high aquaporin 4 expression. Arch Neurol 2006;63:964-968.

4. Wingerchuk DM, Lennon VA, Pittock SJ, Lucchinetti CF, Weinshenker BG. Revised diagnostic criteria for neuromyelitis optica. Neurology 2006;66:1485-1489.

5. Watanabe S, Nakashima I, Misu T, et al. Therapeutic efficacy of plasma exchange in NMO-IgG-positive patients with neuromyelitis optica. Mult Scler 2007;13:128-132

6. Mandler RN, Ahmed W, Dencoff JE. Devic's neuromyelitis optica: a prospective study of seven patients treated with prednisone and azathioprine. Neurology 1998;51:1219-1220.

7. Watanabe S, Misu T, Miyazawa I, et al. Low-dose corticosteroids reduce relapses in neuromyelitis optica: a retrospective analysis. Mult Scler 2007;13:968-974.

8. Takahashi T, Fujihara K, Nakashima I, et al. Anti-aquaporin-4 antibody is involved in the pathogenesis of NMO: a study on antibody titre. Brain 2007;130:1235-1243.
Jarius S, Aboul-Enein F, Waters P, et al. Antibody to aquaporin-4 in the long-term course of neuromyelitis optica. Brain 2008;131: 3072-3080

10. United States Department of Health and Human Services. Agency for Health Care Policy and Research (AHCPR). Acute pain management: operative or medical procedures and trauma. Clinical practice guideline No 1, AHCPR publication No 92-0023. Rockville, MD: AHCPR; 1993.

11. Guyatt G, Gutterman D, Baumann MH, et al. Grading strength of recommendations and quality of evidence in clinical guidelines: report from an American College of Chest Physicians task force. Chest 2006;129:174-181.

12. Gold R, Buttgereit F, Toyka KV. Mechanism of action of glucocorticosteroid hormones: possible implications for therapy of neuroimmunological disorders. J Neuroimmunol 2001;117:1-8.

13. Brusaferri F, Candelise L. Steroids for multiple sclerosis and optic neuritis: a meta-analysis of randomized controlled clinical trials. J Neurol 2000;247:435-442.

14. Nakamura M, Nakazawa T, Doi H, et al. Early high-dose intravenous methylprednisolone is effective in preserving retinal nerve fiber layer thickness in patients with neuromyelitis optica. Graefes Arch Clin Exp Ophthalmol 2010;248:1777-1785.

15. Clark WF, Rock GA, Buskard N, et al. Therapeutic plasma exchange: an update from the Canadian Apheresis Group. Ann Intern Med 1999;131:453-462. 
16. Balogun RA, Kaplan A, Ward DM, et al. Clinical applications of therapeutic apheresis. J Clin Apher 2010;25:250-264.

17. Yoshida H, Ando A, Sho K, et al. Anti-aquaporin-4 antibody-positive optic neuritis treated with double-filtration plasmapheresis. J Ocul Pharmacol 2010;26:381-385.

18. Keller AJ, Urbaniak SJ. Intensive plasma exchange on the cell separator: effects on serum immunoglobulins and complement components. Br J Haematol 1978;38:531-540.

19. Sutton DM, Nair RC, Rock G. Complications of plasma exchange. Transfusion 1989;29:124-127.

20. Keegan M, Pineda AA, McClelland RL, Darby $\mathrm{CH}$, Rodriguez M, Weinshenker BG. Plasma exchange for severe attacks of CNS demyelination: predictors of response. Neurology 2002;58:143-146.

21. Miyamoto K, Kusunoki S. Intermittent plasmapheresis prevents recurrence in neuromyelitis optica. Ther Apher Dial 2009;13:505-508.

22. Cortese I, Chaudhry V, So YT, Cantor F, Cornblath DR, Rae-Grant A. Evidence-based guideline update. Plasmapheresis in neurologic disorders: report of the Therapeutics and Technology Assessment Subcommittee of the American Academy of Neurology. Neurology 2011:76:294-300.

23. Weinshenker BG, O'Brien PC, Petterson TM, et al. A randomized trial of plasma exchange in acute central nervous system inflammatory demyelinating disease. Ann Neurol 1999;46:878-886.

24. Munemoto M, Otaki Y, Kasama S, et al. Therapeutic efficacy of double filtration plasmapheresis in patients with anti-aquaporin-4 antibodypositive multiple sclerosis. J Clin Neurosci 2011;18:478-480.

25. Wang KC, Wang SJ, Lee CL, Chen SY,Tsai CP.The rescue effect of plasma exchange for neuromyelitis optica. J Clin Neurosci 2011;18:43-46.

26. Szczepiorkowski ZM, Winters JL, Bandarenko N, et al. Guidelines on the use of therapeutic apheresis in clinical practice-evidence-based approach from the Apheresis Applications Committee of the American Society for Apheresis. J Clin Apher 2010;25:83-177.

27. Carroll W, Fujihara K. Neuromyelitis optica. Curr Treat Options Neurol 2010;12:244-255.

28. Higgs JE, Payne K, Roberts C, Newman WG. Are patients with intermediate TPMT activity at increased risk of myelosuppression when taking thiopurine medications? Pharmacogenomics 2010:11:177-188.

29. Bichuetti DB, Lobato de Oliveira EM, Oliveira DM, Amorin de Souza N, Gabbai AA. Neuromyelitis optica treatment: analysis of 36 patients. Arch Neurol 2010;67:1131-1136.

30. Tanaka Y, Kimura K, Kawachi I, Inuzuka T. No relapse of neuromyelitis optica during drug-induced B-lymphopenia with hypogammaglobulinemia. Neurology 2010;75:1745-1747.

31. Cree BA, Lamb S, Morgan K, Chen A, Waubant E, Genain C. An open label study of the effects of rituximab in neuromyelitis optica. Neurology 2005;64:1270-1272.

32. Imamura H, Tanaka M, Kitagawa N, et al. Trial of rituximab in three patients with neuromyelitis optica. Rinsho Shinkeigaku 2009;49: 457-462.

33. Capobianco M, Malucchi S, di Sapio A, et al. Variable responses to rituximab treatment in neuromyelitis optica (Devic's disease). Neurol Sci 2007;28:209-211.

34. Nakashima I, Takahashi T, Cree BA, et al. Transient increases in anti-aquaporin-4 antibody titers following rituximab treatment in neuromyelitis optica, in association with elevated serum BAFF levels. J Clin Neurosci 2011;18:997-998.

35. Jacob A, Weinshenker BG, Violich I, et al. Treatment of neuromyelitis optica with rituximab: retrospective analysis of 25 patients. Arch Neurol 2008;65:1443-1448.

36. Bedi GS, Brown AD, Delgado SR, Usmani N, Lam BL, Sheremata WA. Impact of rituximab on relapse rate and disability in neuromyelitis optica. Mult Scler 2011:Epub May 26.
37. Pellkofer HL, Krumbholz M, Berthele A, et al. Long-term follow-up of patients with neuromyelitis optica after repeated therapy with rituximab. Neurology 2011;76:1310-1315.

38. Kim S-H, Kim W, Li XF, Jung I-J, Kim HJ. Repeated treatment with rituximab based on the assessment of peripheral circulating memory $\mathrm{B}$ cells in patients with relapsing neuromyelitis optica over 2 years. Arch Neurol 2011:Epub July 11.

39. Goodin DS, Arnason BG, Coyle PK, Frohman EM, Paty DW. The use of mitoxantrone (Novantrone) for the treatment of multiple sclerosis: report of the Therapeutics and Technology Assessment Subcommittee of the American Academy of Neurology. Neurology 2003;61: 1332-1338.

40. Weinstock-Guttman B, Ramanathan M, Lincoff N, et al. Study of mitoxantrone for the treatment of recurrent neuromyelitis optica (Devic disease). Arch Neurol 2006;63:957-963.

41. Falcini F, Trapani S, Ricci L, Resti M, Simonini G, de Martino M. Sustained improvement of a girl affected with Devic's disease over 2 years of mycophenolate mofetil treatment. Rheumatology 2006;45:913-915.

42. Jacob A, Matiello M, Weinshenker BG, et al. Treatment of neuromyelitis optica with mycophenolate mofetil: retrospective analysis of 24 patients. Arch Neurol 2009;66:1128-1133.

43. The Canadian cooperative trial of cyclophosphamide and plasma exchange in progressive multiple sclerosis. The Canadian Cooperative Multiple Sclerosis Study Group. Lancet 1991;337: 441-446.

44. Weiner HL, Mackin GA, Orav EJ, et al. Intermittent cyclophosphamide pulse therapy in progressive multiple sclerosis: final report of the Northeast Cooperative Multiple Sclerosis Treatment Group. Neurology 1993;43:910-918.

45. Mok CC, To CH, Mak A, Poon WL. Immunoablative cyclophosphamide for refractory lupus-related neuromyelitis optica. J Rheumatol 2008;35:172-174

46. Birnbaum J, Kerr D. Optic neuritis and recurrent myelitis in a woman with systemic lupus erythematosus. Nat Clin Pract Rheumatol 2008;4:381-386.

47. Warabi $Y$, Matsumoto $Y$, Hayashi $H$. Interferon beta- $1 \mathrm{~b}$ exacerbates multiple sclerosis with severe optic nerve and spinal cord demyelination.J Neurol Sci 2007;252:57-61.

48. Shimizu Y, Fujihara K, Kubo S, et al. Therapeutic efficacy of interferon beta-1b in Japanese patients with optic-spinal multiple sclerosis. Tohoku J Exp Med 2011:223:211-214.

49. Uzawa A, Mori M, Hayakawa S, Masuda S, Kuwabara S. Different responses to interferon beta-1b treatment in patients with neuromyelitis optica and multiple sclerosis. Eur J Neurol 2010; 17:672-676.

50. Papeix C, Vidal JS, de Seze J, et al. Immunosuppressive therapy is more effective than interferon in neuromyelitis optica. Mult Scler 2007;13:256-259

51. Palace J, Leite MI, Nairne A, Vincent A. Interferon beta treatment in neuromyelitis optica: increase in relapses and aquaporin 4 antibody titers. Arch Neurol 2010;67:1016-1017.

52. Mayo Clinic. An open label study of the effects of eculizumab in neuromyelitis optica (http://clinicaltrials.gov/ct2/show/ NCT00904826).

53. Hillmen P, Young NS, Schubert J, et al. The complement inhibitor eculizumab in paroxysmal nocturnal hemoglobinuria. N Engl J Med 2006;355:1233-1243

54. Bakker J, Metz L. Devic's neuromyelitis optica treated with intravenous gamma globulin (IVIG). Can J Neurol Sci 2004;31:265-267.

55. Bergamaschi R, Uggetti C, Tonietti S, Egitto MG, Cosi V. A case of relapsing neuromyelitis optica treated with glatiramer acetate. J Neurol 2003;250:359-361. 